Abd El-Aziz S. Fouda ${ }^{1 *}$, Samar A. Abd El-Maksoud², Samar A. Abd El-Salam ${ }^{1}$

${ }^{1}$ El-Mansoura University, Department of Chemistry, Faculty of Science, El-Mansoura, Egypt, ${ }^{2}$ Port Said University, Department of Chemistry, Faculty of Science, Port Said, Egypt

Scientific paper ISSN 0351-9465, E-ISSN 2466-2585 UDC:620.193.4:669.4 doi:10.5937/ZasMat1701005F

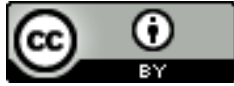

Zastita Materijala 58 (1)

$5-15(2017)$

\title{
Mitigation of corrosion of carbon steel in acid medium using some antipyrine derivatives
}

\begin{abstract}
Adsorption and inhibition efficiency of some antipyrine derivatives on the C-steel (CS) in $1 \mathrm{M} \mathrm{HCl}$ were estimated using three electrochemical techniques (electrochemical impedance spectroscopy (EIS), electrochemical frequency modulation (EFM) and potentiodynamic polarization). Results of polarization showed that these derivatives act as mixed type inhibitors. These derivatives were adsorbed on CS surface following Langmuir adsorption model. EIS results showed that, there was a decrease in double layer capacitance $\left(C_{d l}\right)$ and an increase in charge transfer resistance $\left(R_{c t}\right)$. Three different techniques gave concordant results.
\end{abstract}

Keywords: Corrosion inhibition, carbon steel, $\mathrm{HCl}$, antipyrine derivatives.

\section{INTRODUCTION}

Corrosion is a fundamental process playing an important role in economics and safety, particularly for metals. The use of inhibitors is one of the most practical methods for protection against corrosion, especially in acidic media [1]. Most well-known acid inhibitor are organic compounds containing nitrogen, sulfur, and oxygen atoms. Among them, organic inhibitors have many advantages such as high inhibition efficiency, low price, low toxicity, and easy production [2-5]. Organic heterocyclic compounds have been used for the corrosion inhibition of iron [6-12], copper [13], aluminum [14-16], and other metals $[17,18]$ in different corroding media. The adsorption of the surfactant heterocyclic compounds on the metal surface can markedly change the corrosion-resisting property of the metal $[19,20]$ and so the study of the relations between the adsorption and corrosion inhibition is of great importance. Heterocyclic compounds have shown a high inhibition efficiency for iron in both $\mathrm{HCl}$ [21-24] and $\mathrm{H}_{2} \mathrm{SO}_{4}$ [25] solutions. The effect of two pyrazole-type organic compounds, namely ethyl 5,50-dimethyl-10H-1,30- bipyrazole-3 carboxylate (P1) and 3,5,50-trimethyl-10H-1,30-bipyrazole (P2) on the corrosion behavior of steel in $1 \mathrm{MHCl}$ solution was investigated [26] at $308 \mathrm{~K}$ by

\footnotetext{
*Corresponding author: Abd El-Aziz S. Fouda E-mail: asfouda@hotmail.com

Paper received: 12. 10. 2016.

Paper accepted: 10. 11. 2016.

Paper is available on the website: www.idk.org.rs/journal
}

weight loss measurements, potentiodynamic polarization and impedance spectroscopy (EIS) methods. The inhibition of corrosion of steel in molar hydrochloric acid solution by two bipyrazolic compounds is studied [27] by weight loss and electrochemical polarization measurements. The two methods give consistent results. Some antipyrine compounds have been studied as corrosion inhibitors before [28] we also used some derivatives of it to inhibit corrosion of CS in $1 \mathrm{M} \mathrm{HCl}$. The inhibition effect of vanillin (4-hydroxy-3methoxy-benzaldehyde) and protocatechualdehyde (3,4-dihydroxy-benzaldehyde) in hydrochloric acid medium on steel with known composition has been investigated [29].

The objective of the present work is to investigate the inhibiting action of some antipyrine derivatives in $1 \mathrm{M} \mathrm{HCl}$ at $25^{\circ} \mathrm{C}$ using different electrochemical techniques.

\section{EXPERIMENTAL METHOD}

\subsection{Materials and methods}

The working electrode was made from CS rod. The rod was mounted into a glass tube and fixed by araldite leaving a circle surface geometry of 1 $\mathrm{cm}$ diameter to contact the test solution. Prior to each experiment, the working electrode was polished with a different grades of emery paper up to 1200 grit, rinsed with acetone and finally with doubly distilled water. The auxiliary electrode was platinum wire, while reference electrode was a saturated calomel electrode (SCE). These electrodes were connected to conventional electrolytic cell of capacity $100 \mathrm{ml}$. The experiments were conducted in $1 \mathrm{M} \mathrm{HCl}$ solution and with different 
concentration $\left(1 \times 10^{-6}, 3 \times 10^{-6}, 6 \times 10^{-6}, 9 \times 10^{-6}\right.$, $\left.15 \times 10^{-6}, 18 \times 10^{-6} \mathrm{M}\right)$ of organic compounds. All solutions were freshly prepared using analytical grade reagents and doubly distilled water. All experiments were performed at required temperature $25 \pm 1^{\circ} \mathrm{C}$. The structures, names and molecular weights of the investigated organic compounds are shown below [30] :

\begin{tabular}{|c|c|c|}
\hline $\mathrm{NO}$ & Structures and names & $\begin{array}{c}\text { Chemical Formula and Molecular } \\
\text { weight }\end{array}$ \\
\hline 1 & $\begin{array}{c}\text { 6-(4-methoxyphenyl)-1-methyl-3-oxo-2-phenyl-2,3-dihydro-1 } H \text { - } \\
\text { pyrazolo[4,3- } b \text { ]pyridine-5-carbonitrile }\end{array}$ & $\begin{array}{c}\mathrm{C}_{21} \mathrm{H}_{16} \mathrm{~N}_{4} \mathrm{O}_{2} \\
356.38\end{array}$ \\
\hline 2 & $\begin{array}{c}\mathrm{H}_{3} \mathrm{C} \\
\text { 6-amino-1-methyl-3-oxo-2-phenyl- } \\
\text { 2,3-dihydro-1 } \mathrm{H} \text {-pyrazolo[4,3- } \\
\text { b]pyridine-5-carbonitrile }\end{array}$ & $\begin{array}{c}\mathrm{C}_{14} \mathrm{H}_{11} \mathrm{~N}_{5} \mathrm{O} \\
265.28\end{array}$ \\
\hline
\end{tabular}

Tafel polarization curves were obtained by changing the electrode potential automatically from -500 to $+500 \mathrm{mV}$ at open circuit potential with a scan rate of $1 \mathrm{mVs}^{-1}$. Stern-Geary method [31] used for the determination of corrosion current is performed by extrapolation of anodic and cathodic Tafel lines to a point which gives $\log i_{\text {corr }}$ and the corresponding corrosion potential $\left(\mathrm{E}_{\text {corr }}\right)$ for inhibitor free acid and for each concentration of inhibitor. Then $\mathrm{i}_{\text {corr }}$ was used for calculation of inhibition efficiency and surface coverage $(\theta)$ as below:

IE \% $=\theta \times 100=\left[1-\left(i_{\text {corr(inh) }} / i_{\text {corr(free })}\right] \times 100\right.$

Where $\mathrm{i}_{\text {corr(free) }}$ and $\mathrm{i}_{\text {corr(inh) }}$ are the corrosion current densities in the absence and presence of inhibitor, respectively.

Impedance measurements were carried out in frequency range from $100 \mathrm{kHz}$ to $10 \mathrm{mHz}$ with amplitude of $5 \mathrm{mV}$ peak-to-peak using ac signals at open circuit potential. The experimental impedance were analyzed and interpreted on the basis of the equivalent circuit. The main parameters deduced from the analysis of Nyquist diagram are the resistance of charge transfer $\mathrm{R}_{\mathrm{ct}}$ (diameter of high frequency loop) and the capacity of double layer $\mathrm{C}_{\mathrm{dl}}$ which is defined as:

$$
C_{d l}=1 /\left(2 \pi \text { fmax } R_{c t}\right)
$$

Where $f_{\max }$ is the maximum frequency. The inhibition efficiencies and the surface coverage $(\theta)$ obtained from the impedance measurements were defined by the following relation:

$$
\text { IE \% } \%=\theta \times 100=\left[1-\left(R_{c t}^{\circ} / R_{c t}\right)\right] \times 100
$$

Where $R_{c t}^{\circ}$ and $R_{c t}$ are the charge transfer resistance in the absence and presence of inhibitor, respectively.

The electrode potential was allowed to stabilize 30 min before starting the measurements. All the experiments were conducted at $25 \pm 1^{\circ} \mathrm{C}$. Measurements were performed using Gamry (PCl 300/4) Instrument Potentiostat/Galvanostat/ZRA. This includes a Gamry framework system based on the ESA 400. Gamry applications include DC105 for corrosion measurements and EIS300 for electrochemical impedance spectroscopy along with a computer for collecting data. Echem Analyst 5.58 software was used for plotting, graphing, and fitting data.

\section{RESULTS AND DISCUSSION}

\subsection{Polarization method}

Figures 1\&2 depict the Potentiodynamic polarization curves of $\mathrm{CS}$ immersed in $\mathrm{HCl}$ solution contains different concentrations of inhibitors $1 \& 2$ respectively. The corrosion parameters are presented in Table 1. In the presence of inhibitors, the corrosion potentials are shifted to both cathodic and anodic sides. The largest shift evidenced by 
the two inhibitors system is $34 \mathrm{mV}$ and $31 \mathrm{mV}$. Therefore, it is ensured that the system functions as mixed type inhibitors. Simultaneously, in the presence of inhibitors, the corrosion current decreases (Table 1). The decrease in the corrosion rate indicates that the adsorption of the inhibitors on the metal surface block the active sites and inhibit corrosion and reduce the corrosion rate with the protective film formation on the metal surface.

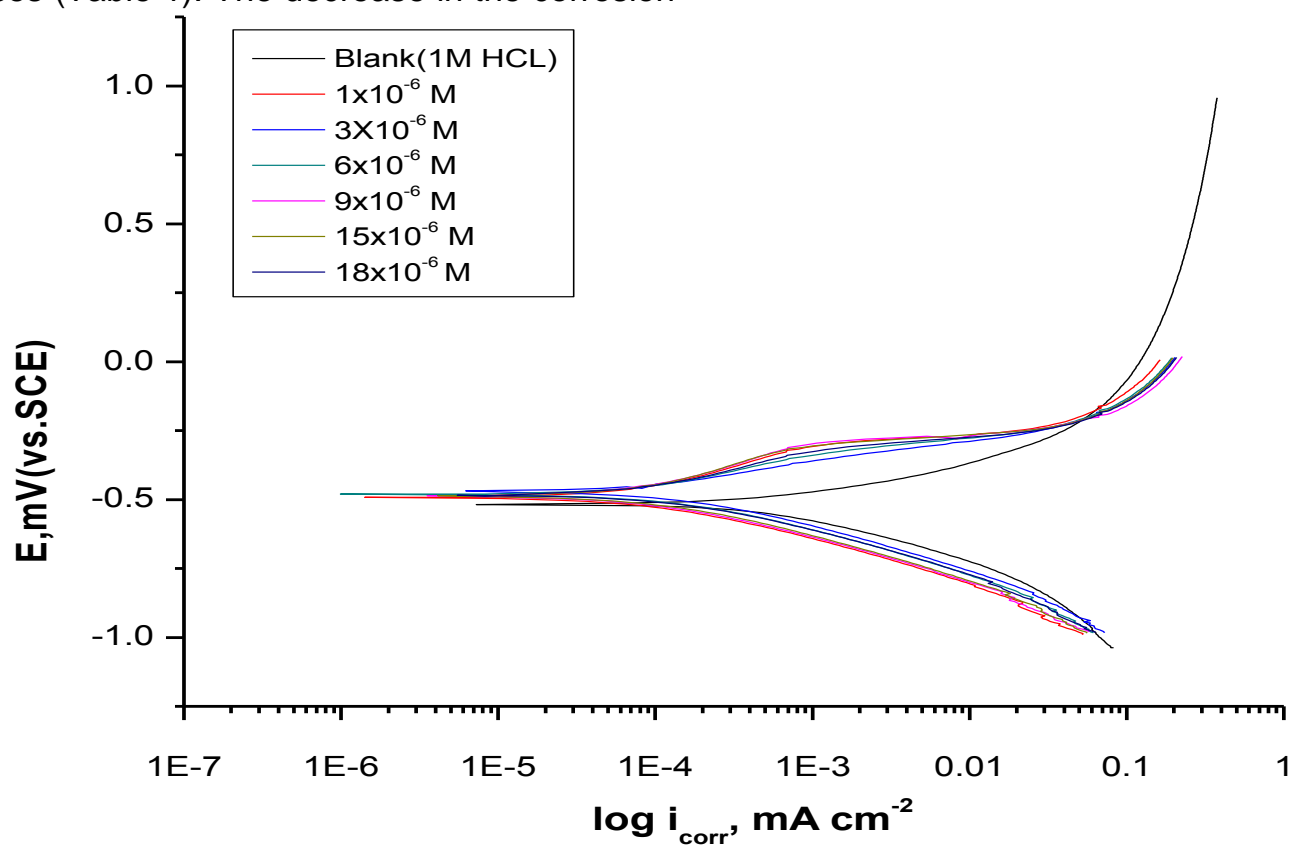

Figure 1. Potentiodynamic polarization curves for the dissolution of CS in $1 \mathrm{M} \mathrm{HCl}$ in the absence and presence of different concentrations of compound (1) at $25^{\circ} \mathrm{C}$

Slika 1. Potentiodinamičke polarizacione krive za CS u $1 \mathrm{M} \mathrm{HCl} \mathrm{u} \mathrm{odsustvu} \mathrm{i} \mathrm{prisustvu} \mathrm{različitih}$ koncentracija jedinjenja (1) na $25^{\circ} \mathrm{C}$

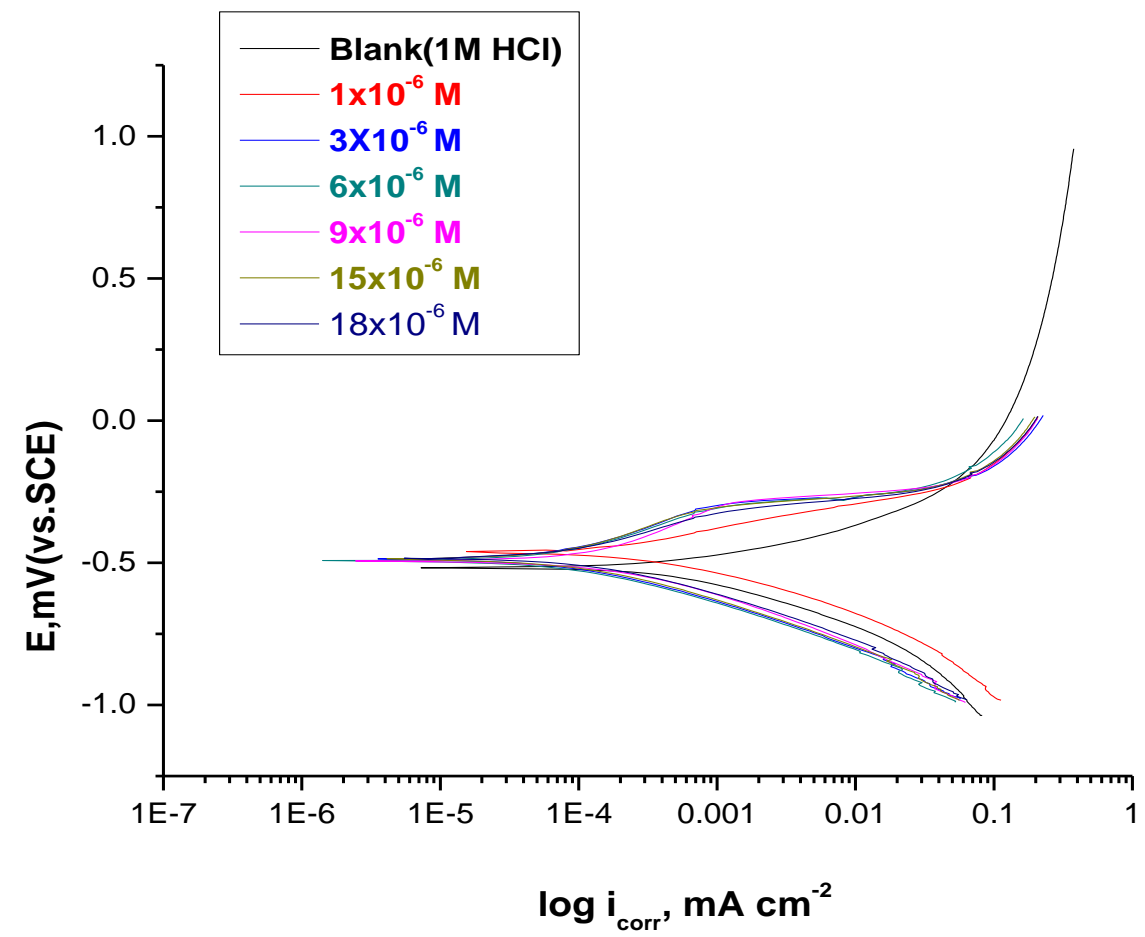

Figure 2. Potentiodynamic polarization curves for the dissolution of CS in $1 \mathrm{M} \mathrm{HCl}$ in absence and presence of different concentrations of compound (2) at $25^{\circ} \mathrm{C}$

Slika 2. Potentiodinamičke polarizacione krive za CS u $1 \mathrm{M} \mathrm{HCl} \mathrm{u} \mathrm{odsustvu} \mathrm{i} \mathrm{prisustvu} \mathrm{različitih}$ koncentracija jedinjenja (2) na $25^{\circ} \mathrm{C}$ 
Table 1. Corrosion parameters of CS immersed in $\mathrm{HCl}$ solution in the absence and presence of various concentrations of investigated inhibitors obtained by polarization method

Tabela 1. Korozioni parametri CS potopljeni u rastvoru $\mathrm{HCl}$ u odsustvu i prisustvu različitih koncentracija ispitivanih inhibitora dobijenih polarizacijonom metodom

\begin{tabular}{|c|c|c|c|c|c|c|c|c|}
\hline$\%$ IE & $\theta$ & $\begin{array}{l}\text { C.R } \\
\text { mpy }\end{array}$ & $\begin{array}{c}\beta_{\mathrm{c}} \\
\mathrm{mV} \mathrm{dec}^{-1}\end{array}$ & $\begin{array}{c}\beta_{\mathrm{a}} \\
\mathrm{mV} \mathrm{dec}^{-1}\end{array}$ & $\begin{array}{c}\mathrm{i}_{\text {corr }} \\
\mu \mathrm{A} \mathrm{cm}^{-2}\end{array}$ & $\begin{array}{c}-E_{\text {corr }} \\
m V \text { vs SCE }\end{array}$ & $\begin{array}{c}\text { inh] } \\
M\end{array}$ & Comp. \\
\hline ---- & ---- & 226.0 & 158 & 113 & 495.0 & 517 & Blank & \multirow{7}{*}{1} \\
\hline 77.5 & 0.775 & 50.8 & 165 & 128 & 111.0 & 492 & $1 \times 10^{-6}$ & \\
\hline 78.5 & 0.785 & 48.4 & 147 & 115 & 106.0 & 471 & $3 \times 10^{-6}$ & \\
\hline 79.3 & 0.793 & 46.8 & 141 & 133 & 102.0 & 481 & $6 \times 10^{-6}$ & \\
\hline 81.0 & 0.810 & 42.5 & 149 & 141 & 93.10 & 487 & $9 \times 10^{-6}$ & \\
\hline 81.5 & 0.815 & 41.9 & 131 & 102 & 91.60 & 487 & $15 \times 10^{-6}$ & \\
\hline 82.4 & 0.824 & 39.7 & 147 & 149 & 87.00 & 484 & $18 \times 10^{-6}$ & \\
\hline 56.4 & 0.564 & 98.8 & 108 & 221 & 216.0 & 462 & $1 \times 10^{-6}$ & \multirow{6}{*}{2} \\
\hline 59.4 & 0.594 & 90.8 & 137 & 238 & 199.0 & 483 & $3 \times 10^{-6}$ & \\
\hline 66.1 & 0.661 & 76.8 & 125 & 235 & 168.0 & 493 & $6 \times 10^{-6}$ & \\
\hline 69.3 & 0.693 & 69.4 & 143 & 231 & 152.0 & 494 & $9 \times 10^{-6}$ & \\
\hline 69.5 & 0.695 & 68.9 & 131 & 223 & 151.0 & 498 & $15 \times 10^{-6}$ & \\
\hline 70.5 & 0.705 & 66.8 & 139 & 251 & 146 & 458 & $18 \times 10^{-6}$ & \\
\hline
\end{tabular}

\subsection{Adsorption isotherm}

Adsorption isotherms are very important in determining the mechanism of organ electrochemical reaction. The most frequently used isotherms are Langmuir, Frumkin, Hill de-Boer, Parsons, Temkin, Flory-Huggin and Freundlich. Basic information on the interaction between the inhibitor and the CS surface can be provided by the adsorption isotherm and in general, inhibitors can function either by physical (electrostatic) adsorption or chemisorptions with the metal. To obtain more information about the interaction between the inhibitors and CS surface, different adsorption isotherms were used. The fractional surface coverage $\theta$ at different concentrations was determined from the potentiodynamic polarization measurements data using the Eq.1. The Langmuir isotherm is presented in the Eq.:

$$
C / \theta=(1 / K)+C
$$

Where $\mathrm{K}$ is the adsorption equilibrium constant, $\mathrm{C}$ is the concentration of the inhibitor. The adsorption equilibrium constant $K$ is related to the free energy of adsorption $\Delta \mathrm{G}^{\circ}$ ads as:

$$
K=1 / 55.5 \exp \left(-\Delta G^{\circ} \text { ads } / R T\right)
$$

$55.5 \mathrm{~mol} \mathrm{dm}^{-3}$ is the molar concentration of water, $R$ is the gas constant, $T$ is thermodynamic temperature in $\mathrm{K}$.

The linear relationship obtained on plotting $\mathrm{C} / \Theta$ as function of $\mathrm{C}$, with slope of unity was shown in Figure 3 . The thermodynamic parameters $\mathrm{K}$ and $\Delta \mathrm{G}^{\circ}$ ads for the adsorption of the studied inhibitors at $25^{\circ} \mathrm{C}$ on CS are obtained by Langmuir adsorption isotherm and are given in Table 2. The negative values of $\Delta \mathrm{G}^{\circ}$ ads for the addition of inhibitors indicate that the process of adsorption of studied inhibitors is spontaneous in nature. The free energy of adsorption of the studied inhibitors 1 \& 2 on CS at $25^{\circ} \mathrm{C}$ was found to be 38.18 and $35.27 \mathrm{~kJ} \mathrm{~mol}^{-1}$ respectively. The calculated adsorption $\Delta \mathrm{G}^{\circ}{ }_{\text {ads }}$ values for the two inhibitors (Table 2) shows that the adsorption is mixed one i.e. physisorption and chemisorptions. Since the values of $\Delta \mathrm{G}^{\circ}{ }_{\text {ads }}$ are less than $40 \mathrm{~kJ} \mathrm{~mol}^{-1}$ and larger than $20 \mathrm{~kJ} \mathrm{~mol}^{-1}$.

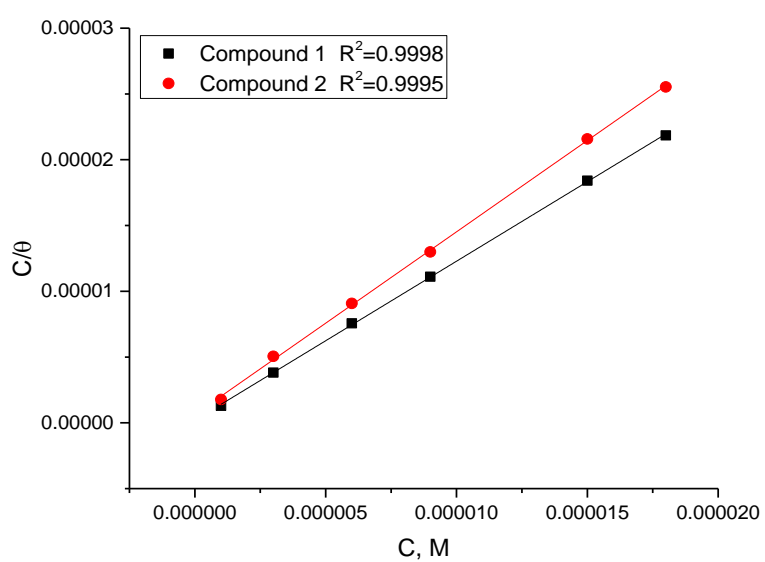

Figure 3. Langmuir adsorption isotherm of studied inhibitors on CS in $1 \mathrm{M} \mathrm{HCl}$ at $25^{\circ} \mathrm{C}$

Slika 3. Langmirova adsorpciona izoterma ispitivanih inhibitora za CS u $1 \mathrm{M} \mathrm{HCl} \mathrm{na} 25^{\circ} \mathrm{C}$

Table 2. Thermodynamic adsorption parameters for the adsorption of studied inhibitors on CS in $1 \mathrm{M} \mathrm{HCl}$ at $25^{\circ} \mathrm{C}$

Tabela 2. Termodinamički adsorpcijski parametri za adsorbciju ispitivanih inhibitora na CS u 1 $\mathrm{M} \mathrm{HCl}$ na $25^{\circ} \mathrm{C}$

\begin{tabular}{|c|c|c|c|}
\hline \multicolumn{3}{|c|}{ Langmuir Isotherm } & \multirow{2}{*}{ Inhibitor } \\
\cline { 1 - 2 } $\begin{array}{c}-\Delta \mathrm{GJ} \mathrm{mol}^{\circ}{ }_{\text {ads. }} \\
\mathrm{KJ} \mathrm{m}^{-1}\end{array}$ & $\begin{array}{c}\mathrm{K} \times 10^{6} \\
\mathrm{M}^{-1}\end{array}$ & Slope & \\
\hline 38.18 & 5.12 & 1.2 & 1 \\
\hline 35.27 & 1.58 & 1.3 & 2 \\
\hline
\end{tabular}




\subsection{Electrochemical frequency modulation (EFM) method}

The EFM technique is used to calculate the anodic and cathodic Tafel slopes as well as the corrosion current densities for the investigated compound. Figures $(4,5)$ show the EFM intermodulation spectra (spectra of current response as a function of frequency) of C-steel alloy in $1 \mathrm{M} \mathrm{HCl}$. The calculated electrochemical parameters ( $i_{\text {corr }}, \beta_{c}$,
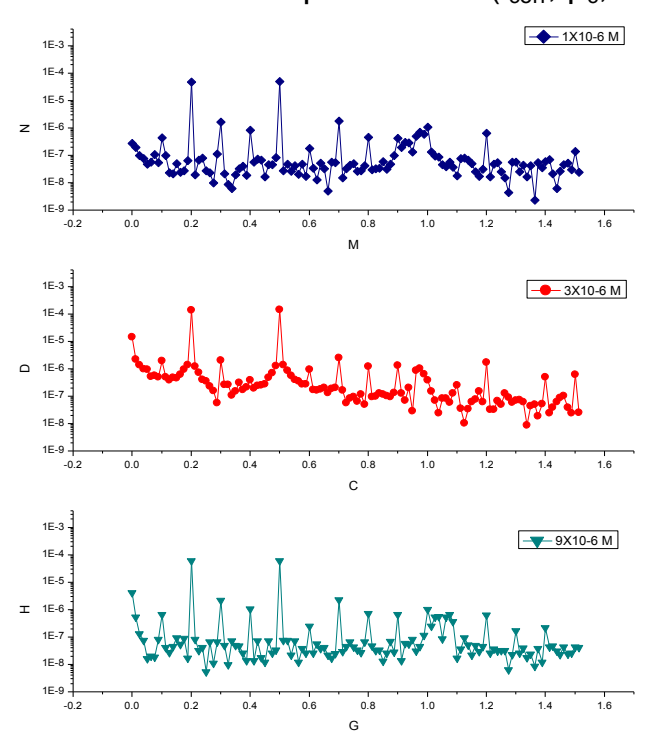

$\beta_{\mathrm{a}}, \mathrm{CF}-2, \mathrm{CF}-3$ and \%IE) are given in Table (3). The values of causality factors obtained in absence and presence of investigated compounds. It shown from the Table that the corrosion current density decreases with increasing the concentration of the investigated compounds with respect to blank and hence the inhibition efficiency increases and indicate that the investigated compounds inhibit the acid corrosion of the alloy through adsorption [32].
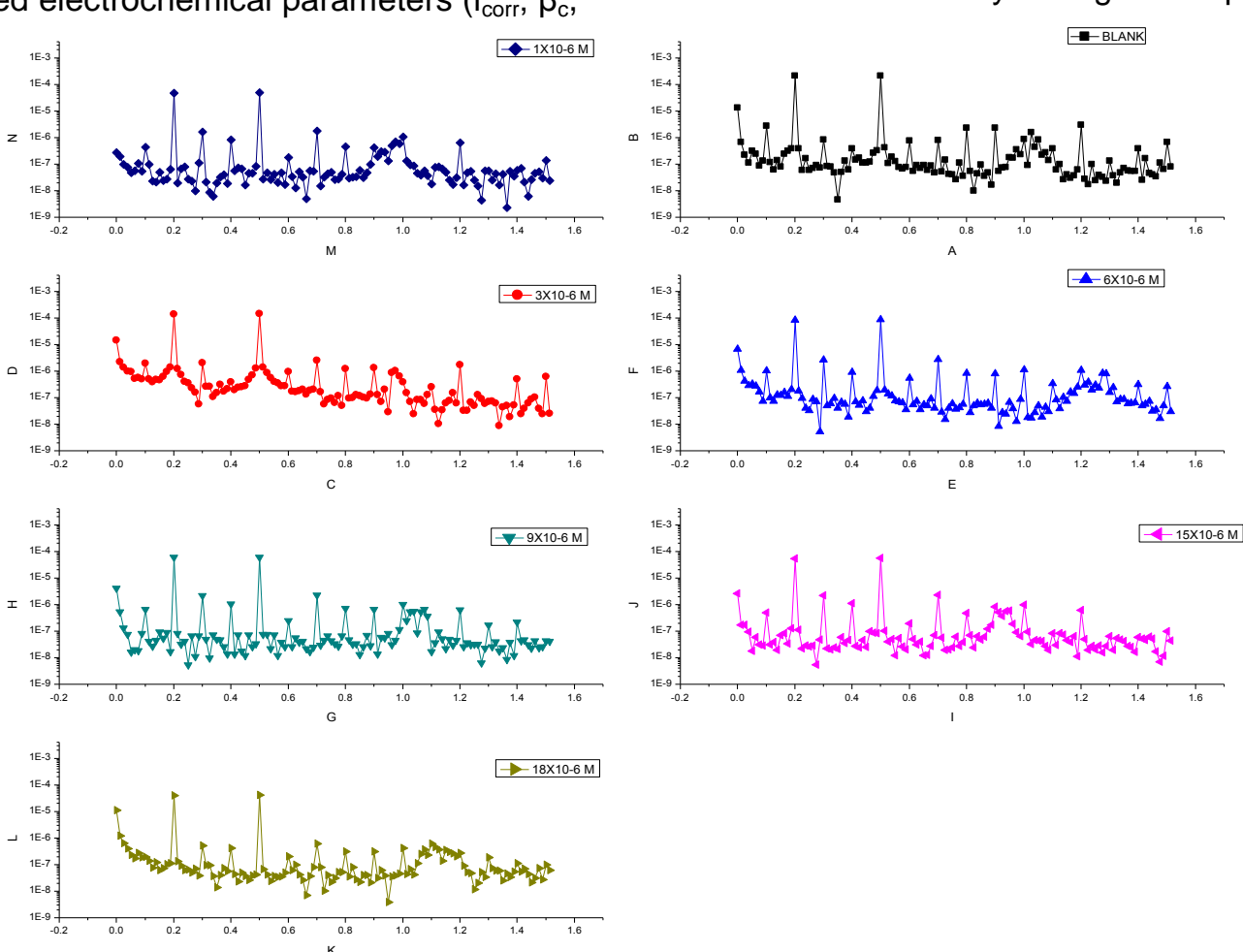

Figure 4. EFM intermodulation spectra of CS in $1 \mathrm{M} \mathrm{HCl}$ for inhibitor (1) at $25^{\circ} \mathrm{C}$ Slika 4. EFM intermodulacijski spektri CS u $1 \mathrm{M} \mathrm{HCl}$ u prisustvu inhibitora (1) na $25^{\circ} \mathrm{C}$

Table 3. Electrochemical parameters for CS determined from potentiodynamic polarization curves in1 $M$ $\mathrm{HCl}$ solution without and with the addition of different concentrations of studied inhibitors at $25^{\circ} \mathrm{C}$

Tabela 3. Elektrohemijski parametri za CS određeni iz potentiodinamičkih polarizacionih krivih u $1 \mathrm{M} \mathrm{HCl}$ bez i sa dodatkom različitih koncentracija ispitivanih inhibitora na $25^{\circ} \mathrm{C}$

\begin{tabular}{|c|c|c|c|c|c|c|c|c|c|}
\hline$\%$ IE & $\Theta$ & $\begin{array}{c}\text { C.R } \\
\mathrm{mpy}\end{array}$ & $\mathrm{CF}-3$ & $\mathrm{CF}-2$ & $\begin{array}{c}\beta_{\mathrm{c}} \\
\mathrm{mVdec}^{-1}\end{array}$ & $\begin{array}{c}\beta_{\mathrm{a}} \\
\mathrm{mVdec}^{-1}\end{array}$ & $\begin{array}{c}\mathrm{i}_{\text {corr }} \\
\mu \mathrm{A} \mathrm{cm}\end{array}$ & $\begin{array}{c}\text { [inh] } \\
\mathrm{M}\end{array}$ & Inhibitor \\
\hline--- & --- & 154.3 & 3.5 & 1.3 & 105.6 & 103 & 337.8 & 0 & Blank \\
\hline 30.8 & 0.308 & 107.8 & 5 & 2 & 115 & 103 & 235.8 & $1 \times 10^{-6}$ & \\
\hline 57.9 & 0.579 & 64.9 & 2.6 & 2.3 & 124 & 100 & 142.1 & $3 \times 10^{-6}$ \\
\hline 68.6 & 0.686 & 48.5 & 4.6 & 2.1 & 128 & 99 & 106.2 & $6 \times 10^{-6}$ & 1 \\
\hline 71.8 & 0.718 & 43.4 & 4 & 2.1 & 130 & 98 & 95.06 & $9 \times 10^{-6}$ & \\
\hline 73.0 & 0.730 & 41.7 & 1.8 & 1.3 & 152 & 135 & 91.27 & $15 \times 10^{-6}$ & \\
\hline 73.2 & 0.732 & 41.3 & 3 & 1.7 & 135 & 105 & 90.41 & $18 \times 10^{-6}$ & \\
\hline 27.4 & 0.274 & 112.2 & 3.5 & 2.3 & 120 & 94 & 245.4 & $1 \times 10^{-6}$ & \\
\hline 45.0 & 0.450 & 84.8 & 2.4 & 2.3 & 139 & 103 & 185.7 & $3 \times 10^{-6}$ \\
\hline 48.7 & 0.487 & 79.2 & 2.7 & 2.3 & 147 & 95 & 173.3 & $6 \times 10^{-6}$ \\
\hline 52.9 & 0.529 & 72.6 & 2.5 & 2.5 & 136 & 94 & 158.8 & $9 \times 10^{-6}$ \\
\hline 56.0 & 0.560 & 67.8 & 2.6 & 2.3 & 146 & 99 & 148.5 & $15 \times 10^{-6}$ \\
\hline 59.4 & 0.594 & 62.7 & 1.9 & 2.2 & 160 & 110 & 137.2 & $18 \times 10^{-6}$ & 2 \\
\hline
\end{tabular}



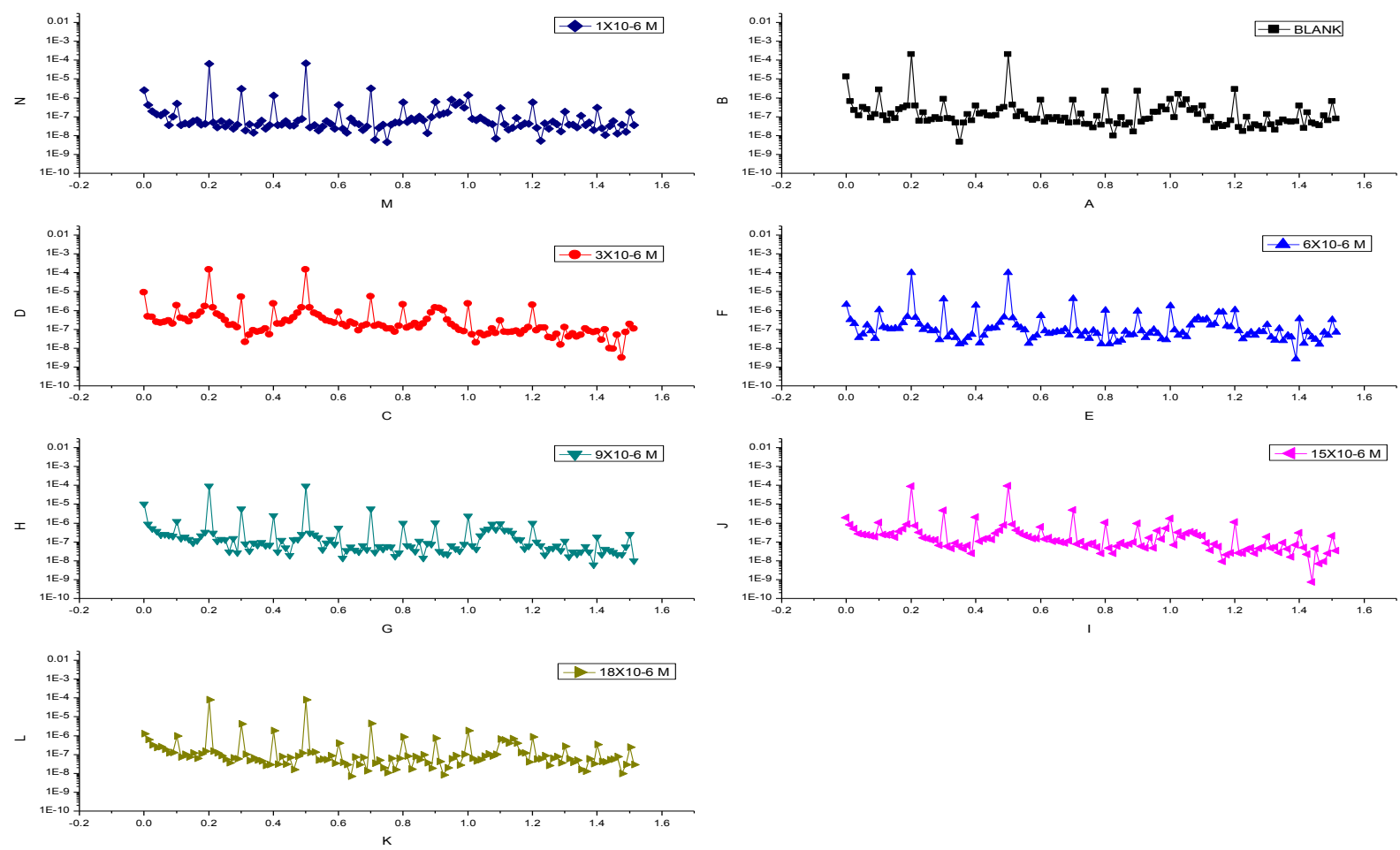

Figure 5. EFM intermodulation spectra of CS in $1 \mathrm{M} \mathrm{HCl}$ for inhibitor (2) at $25^{\circ} \mathrm{C}$

Slika 5. EFM intermodulacijski spektri CS u $1 \mathrm{M} \mathrm{HCl}$ u prisustvu inhibitora (2) na $25^{\circ} \mathrm{C}$

\subsection{Electrochemical impedance spectroscopy} (EIS) method

The effect of inhibitor concentration on the impedance behavior of $\mathrm{CS}$ in $1 \mathrm{M} \mathrm{HCl}$ solution at 25 ${ }^{\circ} \mathrm{C}$ is presented in Figures ( $\left.6 \mathrm{a}, \mathrm{b} \& 7 \mathrm{a}, \mathrm{b}\right)$ as Nyquist and Bode plots. The curves show a similar type of Nyquist plots for CS in the presence of various concentrations of investigated inhibitors. The existence of single semi-circle showed the single charge transfer process during dissolution which is unaffected by the presence of inhibitor molecules. Deviations from perfect circular shape are often referred to the frequency dispersion of interfacial impedance which arises due to surface roughness, impurities, dislocations, grain boundaries, adsorption of inhibitors, and formation of porous layers and in homogenates of the electrode surface [33].

Table 4: Electrochemical kinetics parameters obtained by EIS technique for the investigated inhibitors in $1 \mathrm{M} \mathrm{HCl}$ at $25^{\circ} \mathrm{C}$

Tabela 4. Elektrohemijski kinetički parametri dobijeni EIS tehnikom za ispitivane inhibitore u $1 \mathrm{M} \mathrm{HCl} \mathrm{na}$ $25^{\circ} \mathrm{C}$

\begin{tabular}{|c|c|c|c|c|c|c|}
\hline Inhibitor & $\begin{array}{c}\text { [inh] } \\
M\end{array}$ & $\begin{array}{c}R_{\mathrm{ct}}, \\
\Omega \mathrm{cm}^{2}\end{array}$ & $\begin{array}{c}R_{\mathrm{s}}, \\
\Omega \mathrm{cm}^{2}\end{array}$ & $\begin{array}{c}\mathrm{C}_{\mathrm{dl},}, \\
\mu \mathrm{Fcm}^{-2}\end{array}$ & $\theta$ & $\%$ IE \\
\hline Blank & $1 \mathrm{M} \mathrm{HCl}$ & 63.13 & 1.45 & 6.17 & $\begin{array}{l}---- \\
\end{array}$ & ------ \\
\hline \multirow{6}{*}{1} & $1 \times 10^{-6}$ & 88.6 & 1.55 & 3.34 & 0.760 & 28.7 \\
\hline & $3 \times 10^{-6}$ & 152.2 & 1.42 & 3.41 & 0.801 & 58.5 \\
\hline & $6 \times 10^{-6}$ & 206.2 & 1.34 & 3.93 & 0.862 & 69.4 \\
\hline & $9 \times 10^{-6}$ & 226.1 & 1.31 & 3.20 & 0.892 & 72.1 \\
\hline & $15 \times 10^{-6}$ & 254.5 & 1.44 & 3.88 & 0.911 & 75.2 \\
\hline & $18 \times 10^{-6}$ & 295.8 & 1.18 & 3.24 & 0.921 & 78.6 \\
\hline \multirow{6}{*}{2} & $1 \times 10^{-6}$ & 81.8 & 1.39 & 9.74 & 0.694 & 22.9 \\
\hline & $3 \times 10^{-6}$ & 121.3 & 1.52 & 5.92 & 0.696 & 47.9 \\
\hline & $6 \times 10^{-6}$ & 130.4 & 1.28 & 5.25 & 0.714 & 51.6 \\
\hline & $9 \times 10^{-6}$ & 131.9 & 1.27 & 4.37 & 0.755 & 52.1 \\
\hline & $15 \times 10^{-6}$ & 155.1 & 1.35 & 4.60 & 0.781 & 59.3 \\
\hline & $18 \times 10^{-6}$ & 183.6 & 1.14 & 3.82 & 0.812 & 66.0 \\
\hline
\end{tabular}




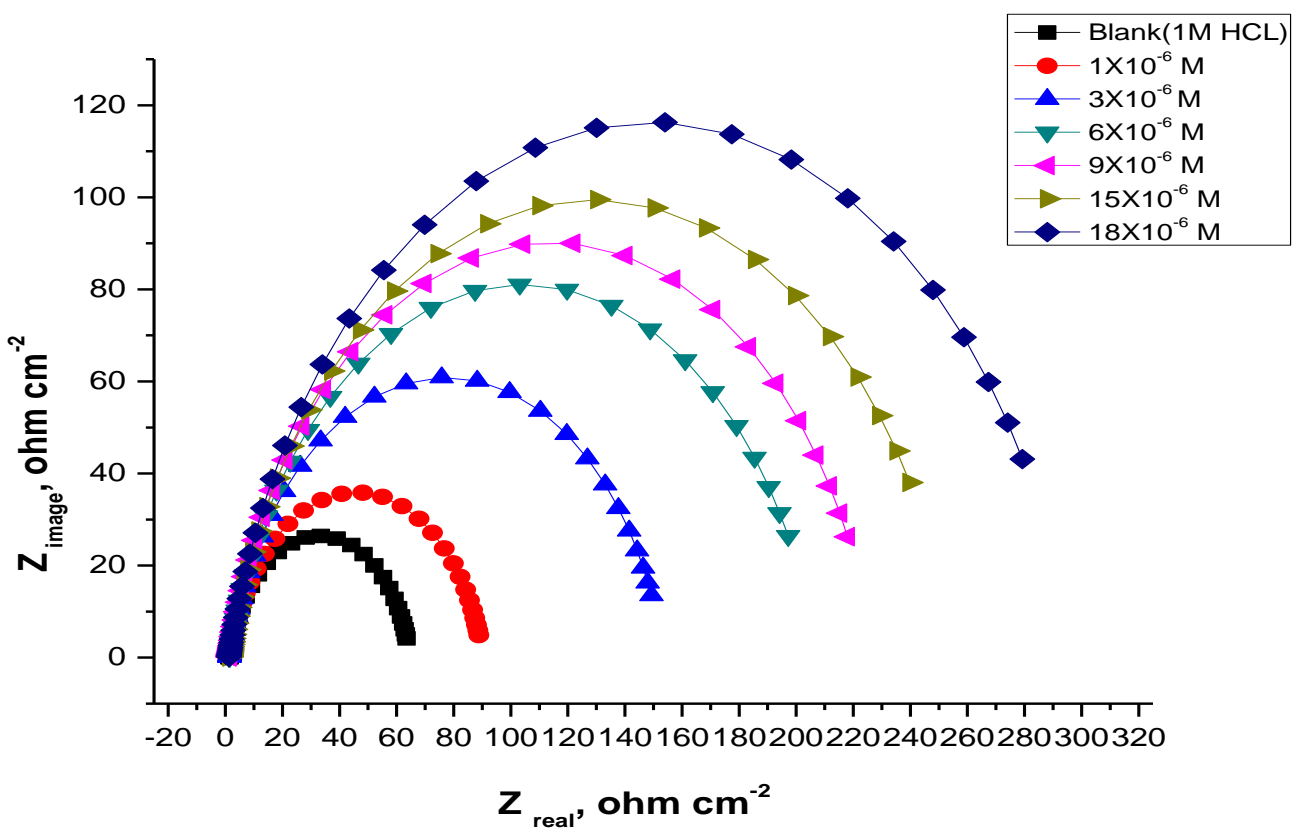

Figure 6a. The Nyquist plots for corrosion of CS in $1 \mathrm{M} \mathrm{HCl}$ in the absence and presence of different concentrations of inhibitor (1) at $25^{\circ} \mathrm{C}$

Slika 6a. Nyquist-ove krive za koroziju CS u $1 \mathrm{M} \mathrm{HCl} \mathrm{u} \mathrm{odsustvu} \mathrm{i} \mathrm{prisustvu} \mathrm{različitih}$ koncentracija inhibitora (1) na $25^{\circ} \mathrm{C}$

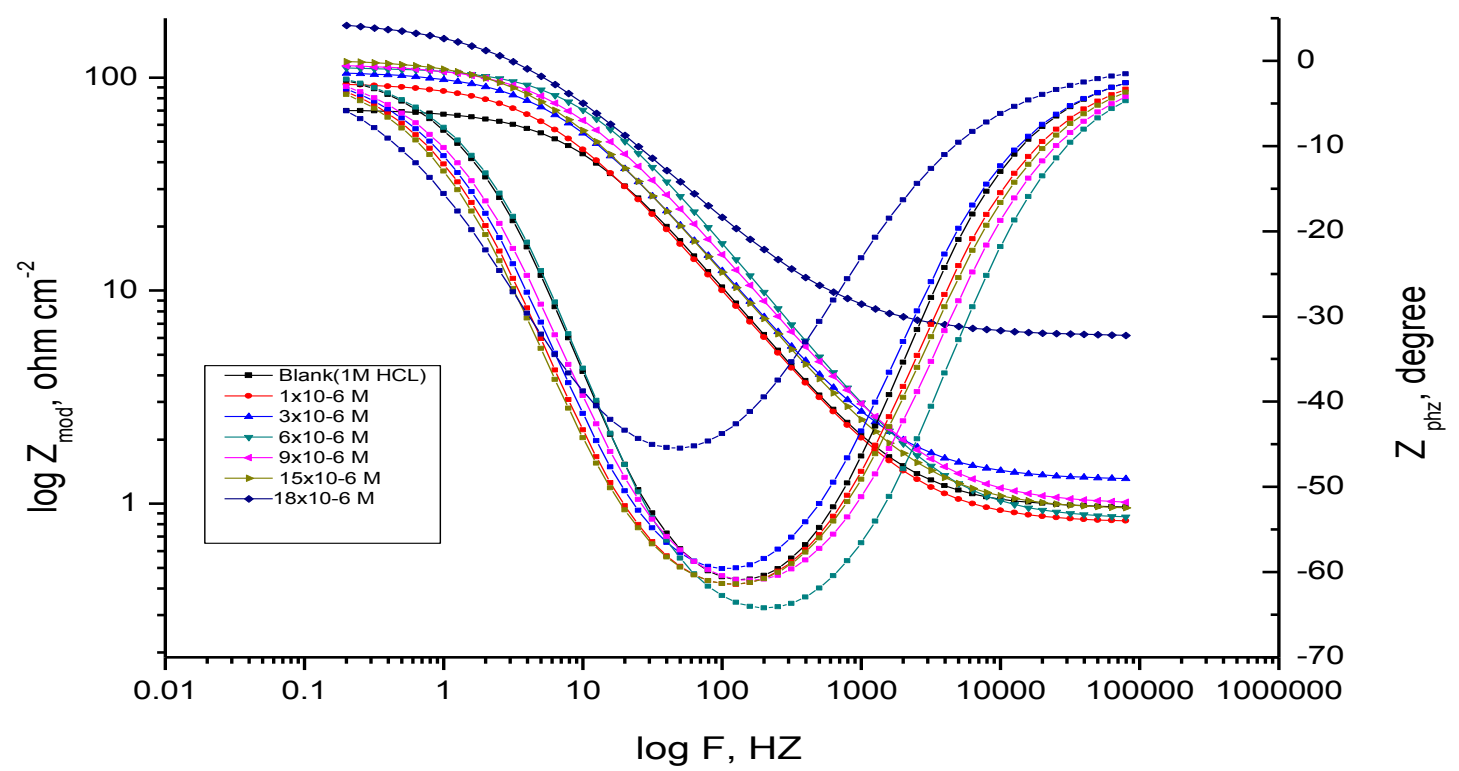

Figure 6b. The Bode plots for corrosion of CS in $1 \mathrm{M} \mathrm{HCl}$ in the absence and presence of different concentrations of inhibitor (1) at $25^{\circ} \mathrm{C}$

Slika 6b. Bode-ove krive za koroziju CS u $1 \mathrm{M} \mathrm{HCl} \mathrm{u} \mathrm{odsustvu} \mathrm{i} \mathrm{prisustvu} \mathrm{različitih}$ koncentracija inhibitora (1) na $25^{\circ} \mathrm{C}$

The AC impedance parameters are given in Table 4. It is obvious from this Table that in presence of inhibitors, the $R_{\mathrm{ct}}$ raises from 63.13 ohm $\mathrm{cm}^{2}$ to 295.8 and $183.6 \mathrm{ohm} \mathrm{cm}^{2}$ for inhibitors $1 \& 2$ respectively and $\mathrm{C}_{\mathrm{dl}}$ decreases from $6.17 \mu \mathrm{F}$ $\mathrm{cm}^{-2}$ to 3.24 and $3,82 \mu \mathrm{F} \mathrm{cm}$ for inhibitors $1 \& 2$ respectively. This decrease in $\mathrm{C}_{\mathrm{dl}}$ and increase in Rct confirmed that the CS dissolution is reduced due to the adsorption of inhibitors on the metal surface that is indicated by the raise in impedance value 


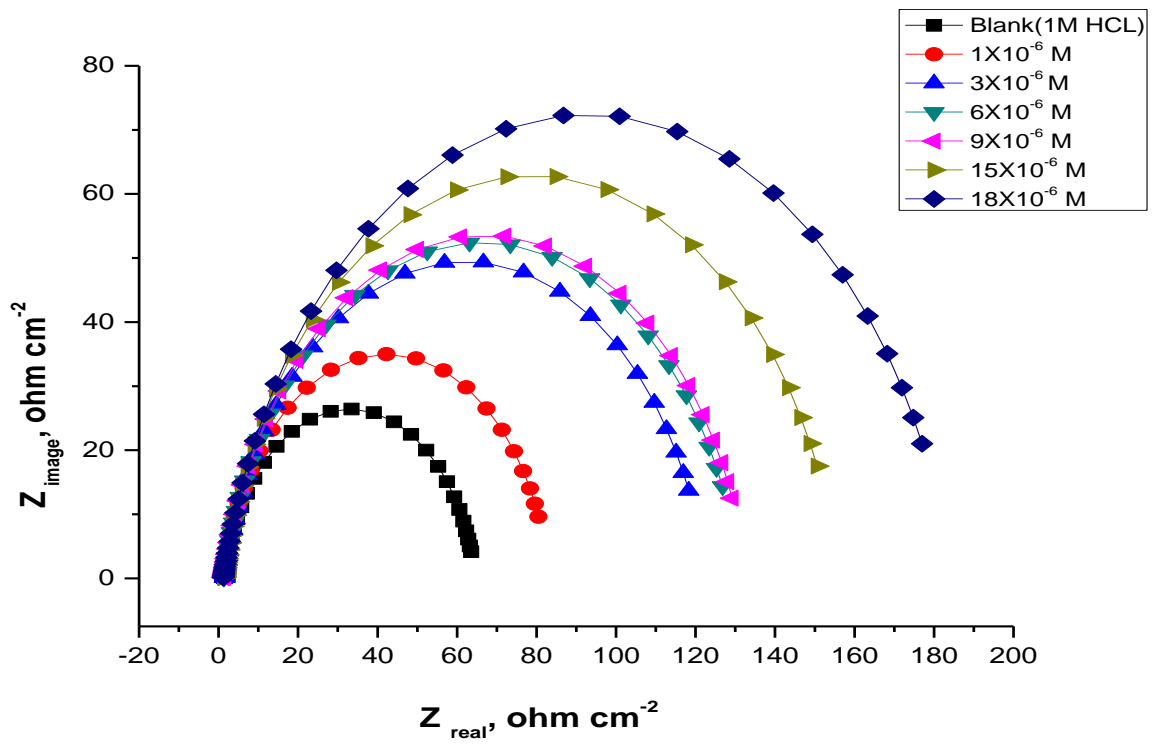

Figure 7a: The Nyquist plots for corrosion of CS in $1 \mathrm{M} \mathrm{HCl}$ in the absence and presence of different concentrations of inhibitor (2) at $25^{\circ} \mathrm{C}$

Slika 7a. Nyquist-ove krive za koroziju CS u $1 \mathrm{M} \mathrm{HCl} \mathrm{u} \mathrm{odsustvu} \mathrm{i} \mathrm{prisustvu} \mathrm{različitih}$ koncentracija inhibitora (2) na $25^{\circ} \mathrm{C}$

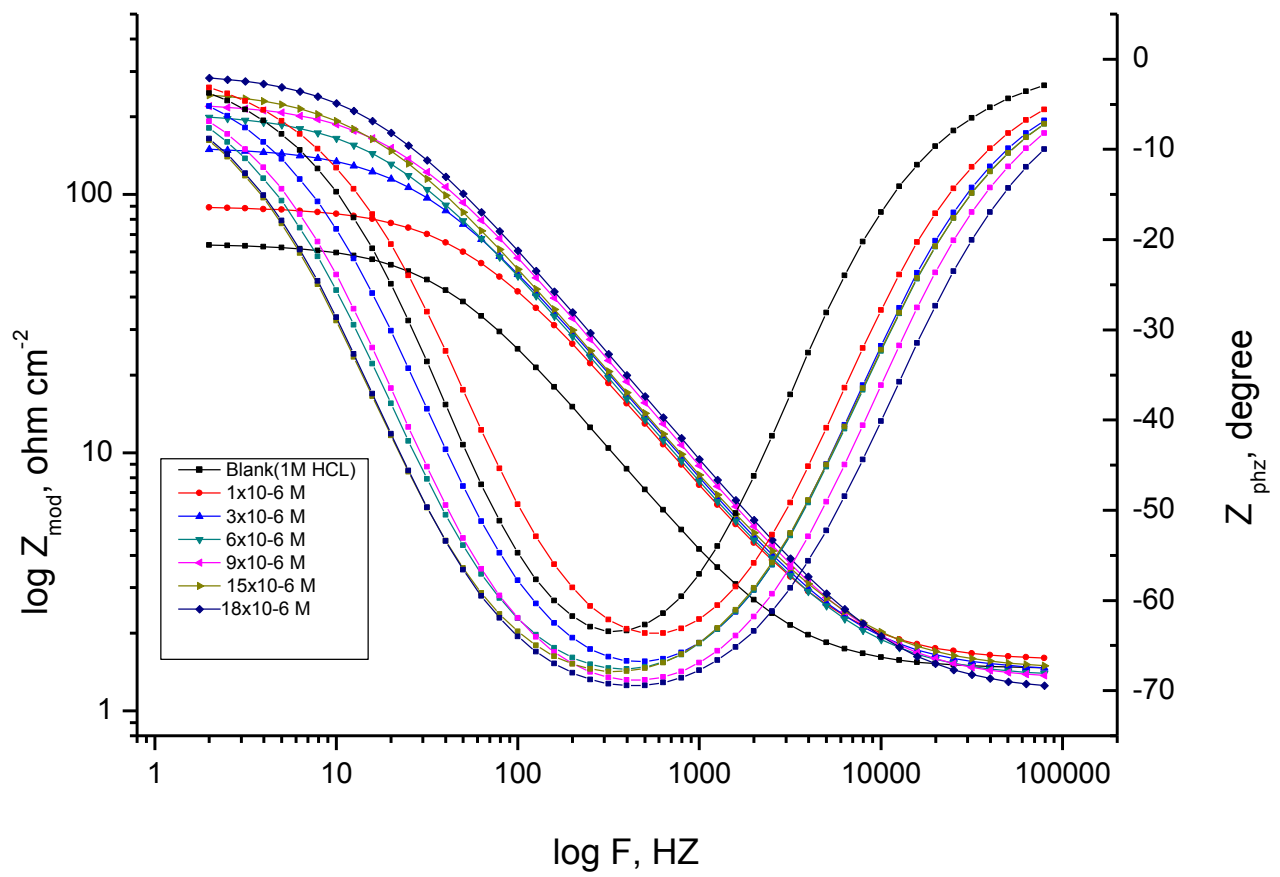

Figure $7 b$. The Bode plots for corrosion of CS in $1 \mathrm{M} \mathrm{HCl}$ in the absence and presence of different concentrations of inhibitor (2) at $25^{\circ} \mathrm{C}$

Slika 7b. Bode-ove krive za koroziju CS u $1 \mathrm{M} \mathrm{HCl} \mathrm{u} \mathrm{odsustvu} \mathrm{i} \mathrm{prisustvu} \mathrm{različitih}$ koncentracija inhibitora (2) na $25^{\circ} \mathrm{C}$

\subsection{Quantum Chemical Study}

It is known that the energy of highest occupied molecular orbital $\left(\mathrm{E}_{\text {номо }}\right)$ often associated with the electron donating ability of the molecules. High values of $\mathrm{E}_{\text {номо }}$ indicate a tendency of the molecule to donate electrons to act with acceptor molecules with low-energy, empty molecular orbital. Similarly, the energy of lowest unoccupied molecular orbital ( $E_{\text {LUMO }}$ ) represents the ability of the molecule to accept electrons. The lower value of $E_{\text {LUMO }}$ suggests that the molecule accepts electrons more probably [34]. The calculated 
quantum chemical indices, $\mathrm{E}_{\text {HOMO }}, \mathrm{E}_{\text {LUMO }}$, energy gap $(\Delta E)$ and dipole moment $(\mu)$, of investigated compounds are calculated and are shown in Table 5. Inhibition efficiency increases with increasing values of $\mathrm{E}_{\text {номо, dipole moment and with decre- }}$ asing values of $E_{\text {LUMO. }}$. The results seem to indicate, that charge transfer from the inhibitor takes place during the adsorption on the metal surface. Increasing values of $\mathrm{E}_{\text {HOMO }}$ and may facilitate adsorption and hence, inhibition by influencing the transport process through the adsorbed layer [35]. Similar relations were found between the inhibition efficiency and the energy gap $\Delta \mathrm{E}$ [36]. Lower values of the energy gap will render good inhibition, because the energy to remove an electron from the last occupied orbital will be low. The dipole moment is another way to obtain data on electronic distribution in a molecule and is one of the properties more used traditionally to discuss and rationalize the structure and reactivity of many chemical systems [37]. The values of $\mathrm{E}_{\mathrm{HOMO}}$ show the relation $1>2$ for this property. In addition, the values of the energy gap $\Delta \mathrm{E}$ show the relation $2>1$ for this property. The results of Table 5 show that the values of $\mu$ (dipole moment) decreases in the following order: $2>1$. Some authors showed that an increase of the dipole moment leads to decrease of inhibition and vice versa, suggesting that lower values of dipole moment will favor accumulation of inhibitor in the surface layer [38]. In contrast, the increase in the dipole moment can lead to increase of inhibition and vice versa [39, 40], which could be related to the dipole-dipole interaction of molecules and metal surface. The higher the value of $\mu$ obtained is coherent with the second explanation indicating stronger dipoledipole interactions of inhibitor molecules and metallic surface.

Table 5. The calculated quantum chemical parameters for investigated inhibitors

Tabela 5. Izračunati hemijski parametri za ispitivane inhibitore

\begin{tabular}{|l|c|c|}
\hline & Compound 1 & Compound 2 \\
\hline$-\mathrm{E}_{\text {HOMO }},(\mathrm{ev})$ & 9.16 & 9.41 \\
\hline$-\mathrm{E}_{\text {LUMO }}(\mathrm{ev})$ & 1.18 & 1.31 \\
\hline$\Delta \mathrm{E},\left(\mathrm{eV} \mathrm{mol}{ }^{-1}\right)$ & 7.96 & 8.10 \\
\hline$\mu,($ Debye $)$ & 7.45 & 6.86 \\
\hline Molecular weight & 356.38 & 265.28 \\
\hline
\end{tabular}

\begin{tabular}{|l|c|c|c|}
\hline Compound 1 Compound 2 \\
\hline Structure & & & \\
\hline Eномо, & & &
\end{tabular}




\subsection{Mechanism of corrosion inhibition}

A clarification of mechanism of inhibition requires full knowledge of the interaction between the protective compound and the metal surface. Many of the organic corrosion inhibitors have at least one polar unit with atoms of nitrogen, sulphur, oxygen and phosphorous. It has been reported that the inhibition efficiency decreases in the order $\mathrm{O}>$ $\mathrm{N}>\mathrm{S}>\mathrm{P}$. In addition iron is well known for its coordination affinity to heteroatom bearing ligands [34]. In $\mathrm{HCl}$ acid medium, molecule exist as protonated species and it is assumed that $\mathrm{Cl}^{-}$ions are first adsorbed on the metal surface and the net positive charge on the metal surface enhances the specific adsorption of chloride ions [41]. Generally, in acid solution the inhibition of metallic corrosion occurs through (i) electrostatic interaction of protonated molecules with already adsorbed chloride ions (ii) donor-acceptor interactions between the $\pi$-electrons of aromatic ring and vacant d-orbital of surface iron atoms (iii) interaction between unshared electron pairs of heteroatoms and vacant d-orbital of iron surface atoms [42]. In the present study, the values of $\Delta \mathrm{G}^{\circ}$ ads are less than $40 \mathrm{~kJ} \mathrm{~mol}^{-1}$. Hence, it shows the adsorption of the inhibitor molecules on the surface of CS predominantly takes place by the physical and chemical adsorption. Compound 1 is more effective corrosion inhibitor than compound 2 . This is due to it has higher molecular size, which may cover larger area from CS surface and also has one additional phenyl ring in its structure.

\section{REFERENCES}

[1] G.Trabanelli (1991) Inhibitors - an old remedy for a new challenge, Corrosion, 47, 410- 419.

[2] D.N.Singh, A.K.Dey (1993) Synergistic Effects of Inorganic and Organic Cations on Inhibitive Performance of Propargyl Alcohol on Steel Dissolution in Boiling Hydrochloric Acid Solution, Corrosion, 49, 594-600.

[3] G.Banerjee, S.N.Malhotra (1992) Contribution to the adsorption of aromatic amines on mild steel surfaces from $\mathrm{HCl}$ solutions by impedance, UV and Raman spectroscopy Corrosion-NACE , 48, 10-15.

[4] S.T.Arab, E.A.Noor (1993) Inhibition of Acid Corrosion of Steel by Some S-Alkylisothiouronium lodides, Corrosion, 49,122-129.

[5] I.A.Raspini (1993) Influence of Sodium Salts of Organic Acids as Additives on Localized Corrosion of Aluminum and Its Alloys, Corrosion, 49, 821-828.

[6] N.Hajjaji, I.Ricco, A.Srhiri, A.Lattes, M.Soufiaoui, A.Benbachir (1993) Effect of N-Alkylbetaines on the Corrosion of Iron in $1 \mathrm{M} \mathrm{HCl}$ Solution, Corrosion, 49 , 326-334.

[7] M.Elachouri, M.S.Hajii, M.Salem, S.Kertit, R.Coudert, E.M.Essassi (1995) Some surfactants in the series of 2-(alkyldimethylammonio) alkanol bromides as inhibitors of the corrosion of iron in acid chloride solution, Corros.Sci., 37, 381-389.

[8] H.Luo, Y.C.Guan, K.N.Han (1998) Inhibition of mild steel corrosion by sodium dodecyl benzene sulfonate and Sodium Oleate in Acidic Solutions, Corrosion, 54, 619-627.
[9] M.A.Migahed, E.M.S.Azzam, A.M.Al-Sabagh (2004) Corrosion inhibition of mild steel in $1 \mathrm{M}$ sulfuric acid solution using anionic surfactant, Mater.Chem. Phys., 85, 273-279.

[10] M.M.Osman, A.M.Omar, A.M.Al-Sabagh (1997) Corrosion inhibition of benzyl triethanol ammonium chloride and its ethoxylate on steel in sulphuric acid solution, Mater. Chem.Phys., 50, 271-274.

[11] A.S.Fouda, A.M. El-Desoky, A.A.Keshk (2014) Inhibitive effect of azine and diazine derivatives on the corrosion of 316L SS in acidic media, Zastita materijala, 55(4), 362-373.

[12] F.Zucchi, G.Trabanelli, G.Brunoro (1992) The influence of the chromium content on the inhibitive efficiency of some organic compounds, Corros. Sci., 33, 1135-1139.

[13] R.F.V.Villamil, P.Corio, J.C.Rubim, M.L.S. Agostinho (1992) Effect of sodium dodecylsulfate on copper corrosion in sulfuric acid media in the absen$\mathrm{ce}$ and presence of benzotriazole, J.Electroanal. Chem., $472,112-119$.

[14] T.P.Zhao, G.N.Mu (1999) The adsorption and corrosion inhibition of anion surfactants on aluminium surface in hydrochloric acid, Corros. Sci., 41, 19371944.

[15] A.S.Fouda, G.Y.Elewady, A.El-Askalany, K.Shalabi (2010) Inhibition of aluminium corrosion in hydrochloric acid media by three Schiff base compound, Zastita materijala, 51(4), 205-221.

[16] S.S. Abd El Rehim, H.Hassan, M.A.Amin (2001) Corrosion inhibition of aluminum by 1,1 (lauryl amido)propyl ammonium chloride in $\mathrm{HCl}$ solution, Mater.Chem.Phys., 70, 64-72.

[17] A.S.Fouda, G.Y.Elewady, M.G.Salama (2010) Corrosion inhibition of aluminium-silicon alloy in $\mathrm{H}_{2} \mathrm{SO}_{4}$ solution using some thiophene derivatives, Zastita materijala, 51(3), 133-143.

[18] S.S.Abd El Rehim, H.Hassan, M.A.Amin (2003) The corrosion inhibition study of sodium dodecyl benzene sulphonate to aluminum and its alloys in $1.0 \mathrm{M} \mathrm{HCl}$ solution, Mater.Chem.Phys., 78,337-348.

[19] R.Guo T.Liu, X.Wei (2002) Effects of SDS and some alcohols on the inhibition efficiency of corrosion for nickel, Colloids Surf., A, 209, 37-45.

[20] V.Branzoi, F.Golgovici, F.Branzoi (2002) Aluminium corrosion in hydrochloric acid solutions and the effect of some organic inhibitors, Mater.Chem. Phys., 78, 122-131.

[21] F.B.Traisnel, M.Lagrenee (2000) The substituted 1,3,4-oxadiazoles: a new class of corrosion inhibitors of mild steel in acidic media, Corros.Sci., 42, 127-146.

[22] A.S.Fouda, M.Morsi, H.A.Mosallim (2016) Capsicum extract as green corrosion extract for carbon steel in Hydrochloric acid solutions, Zastita materijala, 57(1), 33-45.

[23] M.A.B.Christopher, A.R.G.Isabel Jenny (1994) The electrochemical behaviour and corrosion of aluminium in chloride media. The effect of inhibitor anions, Corros. Sci., 36, 915-923.

[24] K.Tebbji, B.Hammouti, H.Oudda, A.Ramdani, M. Benkadour (2005) the inhibitive effect of biprazolic derivatives on corrosion of steel in hydrochloric acid solution , Appl. Surf. Sci, 252, 1378- 1385.

[25] D.B.Chamovska, T.Grchev (2009) Self-passivation of austenitic steel $316 \mathrm{~L}$ and its welded joints in sulphuric acid, Zastita materijala, 50(2), 85-91. 
[26] K.Tebbji, A.Aouniti, M.Benkaddour, H.Ouddac, I. Bouabdallah, B.Hammouti , A.Ramdani (2005) new biprazolic derivatives as corrosion inhibitors of steel in $1 \mathrm{M} \mathrm{HCl}$, in hydrochloric acid solution, Prog. Org. Coat., 54, 170-174.

[27] M.Elachouri, M.S.Hajji, M.Salem, S.Kertit, J.Aride, R.Coudert, E.Essassi (1996) Some Nonionic Surfactants as Inhibitors of the Corrosion of Iron in Acid Chloride Solutions, Corrosion, 52, 103-108.

[28] R.G.Parr, D.A.Donnelly, M. Levy, W.E.Palke (1978) Electronegativity-The density functional viewpoint, J. Chem. Phys., 68, 3801-3807.

[29] A.S.Fouda , S.A.Abd El-Maksoud, S.R.Abd ElSalam (2015) New antipyrine derivatives as corrosion inhibitors for $\mathrm{C}$-steel in $1 \mathrm{M}$ hydrochloric solutions, Elixir Corrosion \& Dye 87, 35511-35517.

[30] K.C.Emregül, M.Hayval (2004) study on the effect of vanillin and protocatchauldhyde on the the corrosion of steel in hydrochloric acid, Mater.Chem.Phys., 83, 209-217.

[31] A.S.Algaber, E.M.El-Nemma, M.M.Saleh (2004) Effect of octylphenol polyethylene oxide on the corrosion inhibition of steel in $0.5 \mathrm{M} \mathrm{H}_{2} \mathrm{SO}_{4}$, Mater. Chem. Phys., 86, 26-32.

[32] A.S.Fouda, A.S.Abousalem, G. Y. EL-Ewady (2016) Mitigation of corrosion of carbon steel in acidic solutions using an aqueous extract of Tilia cordata as green corrosion inhibitor, International Journal of Industrial Chemistry, 1-13., doi:10.1007/s40090016-0102-z.

[33] A.S.Fouda, A.M.Nofal, G.Y.El-Ewady, A.S. Abousalem (2015) Eco-friendly impact of rosmarinus officinalis as corrosion inhibitor for carbon steel in hydrochloric acid solutions, Der Pharma Chemica, 7(5), 183-197.

[34] A.S.Fouda, A.M.Nofal, G.Y.El-Ewady, A.S. Abousalem (2014) Corrosion Inhibition and Thermodynamic Activation Parameters of Arcatium Lappa extract on Mild Steel in Acidic Medium, Chem Sci Rev Lett, 3(12), 1277-1290.
[35] F.M.Reis, H.G.De Melo, I.Costa (2006) EIS investigation on Al 5052 alloy surface preparation for self-assembling monolayer, Electrochimica Acta, 51(8), 1780-1788.

[36] M.E.Mashuga, L.O.Olasunkanmi, A.S.Adekunle, S.Yesudass, M.M.Kabanda, E.E. Ebenso (2015) Adsorption, thermodynamic and quantum chemical studies of 1-hexyl-3-methylimidazolium based ionic liquids as corrosion inhibitors for mild steel in $\mathrm{HCl}$, Materials, 8(6), 3607-3632.

[37] R.Rosliza, W.W.Nik, H.B.Senin (2008) The effect of inhibitor on the corrosion of aluminum alloys in acidic solutions, Materials Chemistry and Physics, 107(2), 281-288.

V.S.Sastri (1998) Corrosion inhibitors: principles and applications (No. Sirsi) i9780471976080).

[38] M.Mahdavian, S.Ashhari (2010) Corrosion inhibition performance of 2-mercaptobenzimidazole and 2 mercaptobenzoxazole compounds for protection of mild steel in hydrochloric acid solution, Electrochimica Acta, 55(5), 1720-1724.

[39] M.Lagrenée, B.Mernari, N.Chaibi, M.Traisnel, H.Vezin, F.Bentiss (2001) Investigation of the inhibitive effect of substituted oxadiazoles on the corrosion of mild steel in $\mathrm{HCl}$ medium, Corrosion science, 43(5), 951-962.

[40] F.Mansfeld (1990) Electrochemical impedance spectroscopy (EIS) as a new tool for investigating methods of corrosion protection, Electrochimica Acta, 35(10), 1533-1544.

[41] E.Blomgren, J.O.M.Bockris (1959) The adsorption of aromatic amines at the interface: mercuryaqueous acid solution, Journal of Physical Chemistry, 63(9), 1475-1484.

[42] I.Ahmed, S.Khan, K.R.Ansari, M.A.Quraishi (2011) primquine a pharmaceticually active compound as corrosion inhibition of mild steel in hydrochloric acid solution, J.Chem.Pharm.Res., 3,703-717.

\title{
IZVOD
}

\section{SMANJENJE KOROZIJE UGLJENIČNOG ČELIKA U KISELOJ SREDINI DODATKOM DERIVATA ANTIPIRINA}

\begin{abstract}
Apsorbciona i inhibicijska efikasnost nekih derivata antipirina na koroziju ugljeničnog čelika u $1 \mathrm{M}$ $\mathrm{HCl}$ procjenjena je pomoću tri elektrohemijske tehnike (merenjem impedanse (EIS), elektrohemijske frekvencije (EFM) i potentiodinamičke polarizacije).

Rezultati polarizacije su pokazali da ovi derivati deluju kao inhibitori mešovitog tipa. Ovi derivati se apsorbuje na površinu ugljeničnih čelika prema Langmuirovom adsorpcionom modelu. EIS rezultati su pokazali da je došlo do pada u kapacitivnosti dvojnog sloja (CDL) i povećanje otpornosti prenosa punjenje (RCT). Tri različite tehnike dale su saglasne rezultate.

Ključne reči: inhibicija korozije, ugljenični čelik, $\mathrm{HCl}$, derivati antipirina.
\end{abstract}

Naučni rad

Rad primljen: 12. 10. 2016.

Rad prihvaćen: 10. 11. 2016.

Rad je dostupan na sajtu: www.idk.org.rs/casopis

(c) 2017 Authors. Published by Inženjersko društvo za koroziju. This article is an open access article distributed under the terms and conditions of the Creative Commons Attribution 4.0 International license (https://creativecommons.org/licenses/by/4.0/) 